\title{
Hour Times Nanogram Per Milliliter Per Milligram Per Gram Per Day
}

National Cancer Institute

\section{Source}

National Cancer Institute. Hour Times Nanogram Per Milliliter Per Milligram Per Gram

Per Day. NCI Thesaurus. Code C117927.

Hour times nanogram per milliliter, divided by milligram per gram per day. 